\title{
Odpowiedzialność administracyjna za zanieczyszczanie wód morskich przez statki
}

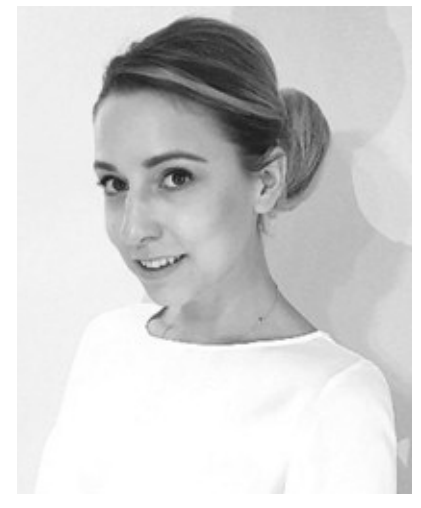

\section{Adrianna Ogonowska}

Doktor nauk prawnych, adiunkt w Instytucie Nauk Prawnych Uniwersytetu Szczecińskiego, ekspert w zakresie prowadzenia szkoleń oraz autorka wielu publikacji z zakresu prawa ochrony środowiska, zwłaszcza dotyczacych odpadów komunalnych oraz ocen oddziaływania na środowisko.

$\triangle$ adrianna.ogonowska@usz.edu.pl https://orcid.org/oooo-0oo1-9536-2618

\section{Administrative Responsibility for Pollution of Sea Waters by Vessels}

\begin{abstract}
The subject of this article is the issue of legal protection of marine water against pollution. Due to the limited scope of the study, only the legal solutions of the administrative liability concerning protection of marine waters against pollution from vessels have been considered. There is no doubt that the degradation of the marine environment is a global problem that often causes irreparable harm to the environment. In the article, there were presented considerations regarding the administrative guarantee of protection of marine waters against pollution from ships. First of all, the concept of administrative liability and its types in environmental protection have been considered. After scrutinizing legal regulations in this range, three basic tools of liability for sea pollution taken by legal enitities have been thoroughly analyzed: the administrative fines imposed on shipowners, the administrative fines imposed on other entities and the revocation of the decision in the range of testing emission reduction methods. Next, the legal regulations concerning the administrative responsibility related to the pollution of sea waters have been assessed.
\end{abstract}

Słowa kluczowe: środowisko morskie, zanieczyszczenia ze statków, prawna ochrona wód morskich, odpowiedzialność administracyjna Key words: marine environment, pollution from vessels, legal protection of marine waters, administrative liability https://doi.org/10.32082/fp.v0i3(59).337

\section{Wstęp}

Środowisko morskie jest wartością o charakterze uniwersalnym. Jego unikatowe właściwości przemawiają za uznaniem go za specyficzną jedność występującą w ramach środowiska.
Określenie zakresów pojęć „środowisko" i „środowisko morskie" sprawia jednak wiele trudności praktycznych. W ustawie $\mathrm{z}$ dnia 27 kwietnia 2001 r. Prawo ochrony 
środowiska ${ }^{1}$ wprowadzono do polskiego porządku prawnego definicję samego środowiska, zgodnie z którą środowisko to ogół elementów przyrodniczych, w tym także przekształconych w wyniku działalności człowieka, oraz wzajemne oddziaływania pomiędzy tymi elementami. Zgodnie $z$ art. 3 pkt 39 p.o.ś. do elementów przyrodniczych zalicza się w szczególności powierzchnia ziemi, kopaliny, wody, powietrze, krajobraz, klimat oraz pozostałe elementy różnorodności biologicznej. U podstaw tej definicji leży założenie, że środowisko jest zbiorem elementów przyrodniczych i określonych stanów faktycznych ${ }^{2}$. Na gruncie polskiego ustawodawstwa, pomimo częstego używania pojęcia „środowisko morskie", nie zostało ono jednak dotychczas zdefiniowane. Środowisko morskie uznaje się w literaturze jako funkcjonalną część środowiska ${ }^{3}$.

Zanieczyszczanie środowiska morskiego, w tym wód morskich, stanowi problem globalny oraz często powoduje nieodwracalne szkody. Pojęcie „zanieczyszczenie” zostało zdefiniowane w art. 3 pkt 49 p.o.ś. Ustawodawca wskazał, że oznacza ono emisję, która może być szkodliwa dla zdrowia ludzi lub stanu, może powodować szkodę w dobrach materialnych, może pogarszać walory estetyczne środowiska lub może kolidować z innymi, uzasadnionymi sposobami korzystania ze środowiska ${ }^{4}$. W rezultacie zanieczyszczenie stanowi emisję kwalifikowaną ze względu na możliwość spowodowania negatywnych skutków ${ }^{5}$. Jak wskazuje Janina Ciechanowicz-McLean, pojęcie zanieczyszczenia jest

1 T.j. Dz. U. 2019, poz. 1396 ze zm. (dalej: p.o.ś.).

2 Szerzej na temat definicji środowiska w p.o.ś.: M. Pchałek (w:) M. Górski i in. (red.), Prawo ochrony środowiska. Komentarz, Warszawa 2014, s. 82-83; B. Rakoczy (w:) Z. Bukowski i in. (red.), Prawo ochrony środowiska. Komentarz, Warszawa 2013, s. 49-50; B. Rakoczy (w:) J. Ciechanowicz-McLean, Z. Bukowski, B. Rakoczy (red.), Prawo ochrony środowiska. Komentarz, Warszawa 2008, s. 46-47; M Górski (w:) J. Jendrośka (red.), Prawo ochrony środowiska. Komentarz, Wrocław 2001, s. 81-83.

3 D. Pyć, I. Zużewicz-Wiewórska (red.), Leksykon prawa morskiego. 100 podstawowych pojęć, Warszawa 2013, s. 545.

4 Szerzej na temat definicji zanieczyszczenia w p.o.ś. zob.: M. Górski (w:) M. Górski i in., Prawo ochrony środowiska. Komentarz, Warszawa 2014, s. 87-88.

5 Tamże, s. 87. węższe od emisjí. Ponadto, ze względu na negatywne skutki, w odróżnieniu od emisji, zanieczyszczenie cechuje nielegalność 7 .

W ustawie z dnia 16 marca 1995 r. o zapobieganiu zanieczyszczaniu morza przez statki ${ }^{8}$ ustawodawca zrezygnował ze zdefiniowania pojęcia „zanieczyszczenie”. Wprowadził natomiast definicję substancji zanieczyszczających ${ }^{9}$, określając, że są nimi substancje wskazane w dwóch załącznikach do międzynarodowej konwencji o zapobieganiu zanieczyszczeniu morza przez statki, sporządzonej w Londynie dnia 2 listopada 1973 r. (1 i 2) $)^{10}$. Dodatkowo u.z.z.m.s. zawiera odesłania do stosowania postanowień kilku umów międzynarodowych, w tym konwencji o ochronie środowiska morskiego obszaru Morza Bałtyckiego, sporządzonej w Helsinkach dnia 9 kwietnia 1992 r. ${ }^{11}$, w której definicja taka została sformułowana.

Zgodnie z brzmieniem art. 2 ust. 1 Konwencji helsińskiej z 1992 r. zanieczyszczeniem jest wprowadzenie przez człowieka bezpośrednio lub pośrednio do morza, łącznie z ujściami rzek, substancji lub energii, które mogą stwarzać zagrożenie dla zdrowia człowieka, niszczyć żywe zasoby i morskie ekosystemy, stwarzać utrudnienie w dozwolonym użytkowaniu morza łącznie z rybołówstwem, pogarszać jakość użytkowanej wody morskiej oraz prowadzić do zmniejszenia walorów rekreacyjnych morza.

Pojęcie „zanieczyszczenie morza” zostało wprowadzone do dyrektywy Parlamentu Europejskiego i Rady 2008/56/WE z dnia 17 czerwca 2008 r. ustanawiającej ramy działań Wspólnoty w dziedzinie polityki środowiska morskiego ${ }^{12}$. W art. 3 pkt 8 dyrektywy wskazano, że zanieczyszczenie morza oznacza spowodowane przez działalność człowieka bezpośrednie lub pośrednie wprowadzanie do środowiska morskiego substancji lub energii, $\mathrm{w}$ tym również podmorskiego

6 J. Ciechanowicz-McLean, Prawo ochrony i zarządzania środowiskiem, Warszawa 2015, s. 27.

7 Tamże.

8 T.j. Dz.U. 2017, poz. 2000 ze zm. (dalej: u.z.z.m.s.).

9 Art. 4 pkt 6 u.z.z.m.s.

10 Dz.U. 1987, nr 17, poz. 101 (dalej: Konwencja Marpol).

11 Dz.U. 2000, nr 28, poz. 346 (dalej: Konwencja helsińska z 1992 r.).

12 Dz.Urz.UE.L 164 z 25 czerwca 2008 r., s. 19 ze zm. 
hałasu będącego wynikiem działalności człowieka, co powoduje lub może powodować negatywne skutki, takie jak szkody w żywych zasobach i ekosystemach morskich, w tym utratę różnorodności biologicznej, zagrożenie dla zdrowia ludzkiego, utrudnienia w działalności morskiej, w tym dla rybołówstwa, turystyki i rekreacji, oraz w innych zgodnych z prawem sposobach korzystania z morza, jak również pogorszenie jakości użytkowanej wody morskiej i zmniejszenie walorów estetycznych lub też - ogólnie - pogorszenie możliwości zrównoważonego użytkowania zasobów i usług morskich. Należy zauważyć, że definicja ta jest podobna do definicji zawartej w konwencji Narodów Zjednoczonych o prawie morza, sporządzona w Montego Bay 10 grudnia 1982 r. $^{13}$ Uwypuklono w niej jednak możliwość powodowania zanieczyszczeń przez podmorski hałas oraz rozszerzono katalog przykładowych negatywnych skutków tego zjawiska.

Na gruncie obecnie obowiązującego porządku prawnego, zgodnie z art. 2 ust. 4 p.o.ś., zasady ochrony morza przed zanieczyszczeniem przez statki oraz organy administracji właściwe w sprawach tej ochrony są określone odrębnymi przepisami. W rezultacie, co do zasady, sfera ochrony wód morskich przed zanieczyszczeniami przez statki pozostaje poza zakresem zastosowania ustawy Prawo ochrony środowiska ${ }^{14}$. Stosowane są natomiast rozwiązania zawarte w przepisach odrębnych, co oznacza konieczność uwzględniania nie tylko aktów prawa wewnętrznego. Wśród aktów pierwszej kategorii należy wskazać przede wszystkim na: ustawę o zapobieganiu zanieczyszczaniu morza przez statki, ustawę Prawo wodne, ustawę Kodeks morski oraz ustawę z dnia 15 maja 2015 r. o substancjach zubożających warstwę ozonową (wraz z aktami wykonawczymi do wymienionych ustaw $)^{15}$.

W ramach regulacji prawnych chroniących wody morskie przed zanieczyszczeniami na szczególną uwagę zasługują przepisy regulujące działania o cha-

13 Dz.U. 2002, nr 59, poz. 543.

14 Wyrok Wojewódzkiego Sądu Administracyjnego w Gdańsku z 21 czerwca 2007 r., II SA/Gd 257/07, Legalis nr 112296.

15 K. Gruszecki, Prawo ochrony środowiska. Komentarz, Warszawa 2016, s. 57; B. Rakoczy (w:) J. Ciechanowicz-McLean, Z. Bukowski, B. Rakoczy (red.), Prawo ochrony środowiska. Komentarz, Warszawa 2008, s. 38. rakterze gwarancyjnym dotyczące odpowiedzialności z tytułu zanieczyszczeń wód morskich. System przepisów o odpowiedzialności prawnej związanej z obowiązkami dotyczącymi wód morskich obejmuje w zakresie odpowiedzialności administracyjnej przepisy u.z.z.m.s. regulujące administracyjne kary pieniężne obciążające armatora i inne podmioty oraz instrument prawny w postaci cofnięcia decyzji administracyjnej dotyczącej wyrażenia zgody na stosowanie metod redukcji emisji.

W niniejszym opracowaniu dokonano pogłębionej analizy oraz oceny polskich regulacji prawnych w zakresie odpowiedzialności administracyjnej ponoszonej za zanieczyszczanie wód morskich przez statki. Jako metodę badawczą przyjęto analizę materiału normatywnego oraz literatury przedmiotu.

\section{Istota i funkcje odpowiedzialności administracyjnej w ochronie środowiska}

Obecnie w literaturze pojęcie odpowiedzialności prawnej najczęściej definiowane jest jako odpowiedzialność oparta na normach prawnych, które określają obowiązek i sposób rozliczenia z jego wykonania $^{16}$. Początkowa rozważania dotyczące odpowiedzialności administracyjnej koncentrowały się wokół uznania jej za szczególną postać przymusu administracyjnego stosowaną przez organy administracji, której podstawę stanowi czyn bezprawny, niekoniecznie zawiniony ${ }^{17}$. Z kolei Jan Boć wskazał, że odpowiedzialność administracyjna to regulowana prawem możliwość uruchomienia wobec określonego podmiotu z powodu jego działalności naruszającej stan środowiska środków prawnych realizowanych w swoistych dla administracji formach i procedurach ${ }^{18}$. Pojęcie odpowiedzialności administracyjnej zdefinio-

16 Szerzej: M. Górski, Obowiązek dbania o środowisko (w:) M. Safjan, L. Bosek (red.), Konstytucja RP. Komentarz, tom I, Warszawa 2016, s. 1901-1902; por. także B. Rakoczy, Ewolucja koncepcji odpowiedzialności w polskim prawie ochrony środowiska (w:) M. Rudnicki, A. Haładyj, K. Sobieraj (red.), Europeizacja prawa ochrony środowiska, Lublin 2011, s. 379-392.

17 W. Radecki, Odpowiedzialność administracyjna wochronie środowiska, Wrocław 1985, s. 56-69.

18 J. Boć, K. Nowacki, E. Samborski-Boć, Ochrona środowiska, Wrocław 2005, s. 396. 
wane zostało również przez Aleksandra Lipińskiego. Autor ten czyni to w sposób opisowy, wskazując, że są to ustalone przez organ administracji publicznej nakazy, zakazy określonego zachowania się, dotyczące zazwyczaj wstrzymania działalności, cofnięcia decyzji zezwalającej na oznaczony sposób korzystania ze środowiska, wykonania stosownych urządzeń ochronnych, usunięcia stwierdzonych uchybień lub szkodliwych następstw ${ }^{19}$. W konsekwencji w definicji A. Lipińskiego zauważalne jest odniesienie się do poszczególnych instrumentów odpowiedzialności administracyjnej.

Obecnie w doktrynie prawa ochrony środowiska podkreśla się, że odpowiedzialność administracyjna to odpowiedzialność egzekwowana przez organy administracji, zwłaszcza poprzez wydawanie decyzji administracyjnych ${ }^{20}$. W konsekwencji cechą odpowiedzialności administracyjnej jest powstanie stosunku administracyjno-prawnego, który łączy organ administracji publicznej oraz podmiot, wobec którego działanie organu jest skierowane ${ }^{21}$. Istotny jest również pogląd Kamili Kwaśnickiej, która uważa, że odpowiedzialność administracyjna to ponoszenie przez administrowanych przewidzianych prawem sankcji, wymierzanych w swoistej procedurze administracyjnej ${ }^{22}$. Wskazana definicja odpowiedzialności administracyjnej oparta jest na definicji zaproponowanej przez Ryszarda Paczuskiego ${ }^{23}$.

Sankcje administracyjne nakładane są w drodze decyzji administracyjnych w postępowaniu prowadzonym zgodnie z przepisami ustawy z dnia 14 czerwca

19 A. Lipiński, Prawne podstawy ochrony środowiska, Kraków 2005, s. 415; por. także J. Skoczylas, Pojęcie i rodzaje odpowiedzialności prawnej w ochronie środowiska, „Zeszyty Naukowe Szkoły Głównej Służby Pożarniczej” 2011, nr 41, s. 121.

20 M. Górski (w:) M. Górski i in., Prawo ochrony środowiska..., s. 931.

21 Tamże.

22 K. Kwaśnicka, Odpowiedzialność administracyjna w prawie ochrony środowiska, Warszawa 2011, s. 71.

23 Por. R. Paczuski, Prawo ochrony środowiska, Bydgoszcz 2000, s. 136; W. Lang, Struktura odpowiedzialności prawnej, „Zeszyty Naukowe Uniwersytetu Mikołaja Kopernika” 1986, z. 8 (31): Prawo, VIII, s. 12.
1960 r. Kodeks postępowania administracyjnego ${ }^{24}$. Ciężar dowodu w postępowaniu administracyjnym dotyczącym odpowiedzialności administracyjnej spoczywa na organie administracji publicznej. To na organie ciąży obowiązek wykazywania przesłanek odpowiedzialności, jednak w przypadku odpowiedzialności administracyjnej, ze względu na brak potrzeby wykazywania powstania szkody, winy oraz bezprawności czynu, zadanie to zostało znacznie ułatwione ${ }^{25}$. Do przesłanek pociągnięcia do odpowiedzialności administracyjnej należą: istnienie określonego obowiązku związanego z zapobieganiem zanieczyszczaniu wód morskich przez statki, obciążającego dany podmiot, oraz dolegliwość ponoszona w związaniu $z$ naruszeniem normy prawnej ${ }^{26}$. Dlatego w pierwszej kolejności należy sprawdzić, czy na podmiocie ciążył obowiązek określonego zachowania, a następnie czy został on wykonany. Po ustaleniu tych okoliczności organ podejmuje czynności zmierzające do wykonania zachowania będącego przedmiotem obowiązku, a następnie do zastosowania środków represyjnych.

Odpowiedzialność administracyjna nie jest uzależniona od stwierdzenia winy. Dlatego nie bada się stopnia zawinienia strony ani okoliczności, które mogłyby wyłączyć odpowiedzialność w tym zakresie ${ }^{27}$. Wystarczające jest stwierdzenie samego naruszenia prawa lub ostatecznej decyzji administracyjnej, czyli obiektywnie ujęte bezprawie administracyjne. Jest to odpowiedzialność typu gwarancyjnego, czyli odpowiedzialność za skutek ${ }^{28}$. W rezultacie wykazanie winy, szkody oraz związku kauzalnego nie jest wymagane.

24 T.j. Dz.U. 2018, poz. 2096 ze zm. (dalej: k.p.a.). Por. także J. Jerzmański, Odpowiedzialność administracyjna (w:) Instytucje prawa ochrony środowiska. Geneza, rozwój, perspektywy, Warszawa 2010, s. 399.

25 B. Rakoczy, Ciężar dowodu w polskim prawie ochrony środowiska, Warszawa 2010, s. 137.

26 Tamże, s. 128-129.

27 Wyrok Wojewódzkiego Sądu Administracyjnego w Krakowie z dnia 21 lipca 2016 r., II SA/Kr 541/16, LEX nr 2104905; wyrok Naczelnego Sądu Administracyjnego z dnia 3 stycznia 1983 r., I SA 1517/83, niepubl.

28 P. Sadowski, Odpowiedzialność administracyjna w ochronie środowiska (w:) J. Stelmasiak (red.), Prawo ochrony środowiska, Warszawa 2009, s. 121. 
W przypadku odpowiedzialności administracyjnej za zanieczyszczanie wód morskich przez statki zdarzeniem podlegającym ujemnej kwalifikacji normatywnej jest naruszenie obowiązków prawnych, obciążających różne podmioty. Za formy odpowiedzialności administracyjnej w badanym zakresie należy uznać różnego rodzaju środki administracyjne stosowane przez organy administracji publicznej (zwłaszcza przez dyrektora urzędu morskiego), będące następstwem naruszenia wymogów ochrony wód morskich ustanowionych aktami prawnymi w zakresie ochrony wód morskich.

Prawnymi instrumentami odpowiedzialności administracyjnej istotnymi z punktu widzenia ochrony wód morskich są przede wszystkim administracyjne kary pieniężne. O ile traktowanie nakładania administracyjnych kar pieniężnych jako przejawów odpowiedzialności prawnej ${ }^{29}$ nie budzi wątpliwości, o tyle samo zakwalifikowanie ich do odpowiedzialności administracyjnej - już tak ${ }^{30}$. W doktrynie prawa ochrony środowiska administracyjne kary pieniężne uznawane są za prawne środki realizacji odpowiedzialności administracyjnej przez wielu autorów ${ }^{31}$.

29 Jak zauważa W. Radecki, w przypadku administracyjnych kar pieniężnych pojawiają się elementy charakterystyczne dla odpowiedzialności prawnej, tj. ujemna kwalifikacja normatywna w postaci naruszenia wymagań ochrony środowiska, ujemna konsekwencja tej kwalifikacji w postaci konieczności zapłacenia określonej sumy pieniężnej oraz przypisanie tej konsekwencji podmiotowi, który dokonał naruszenia. W. Radecki, Opłaty i kary pieniężne w ochronie środowiska, Warszawa 2009, s. 76.

30 Por. M. Mazurkiewicz, Opłaty i kary pieniężne w systemie ochrony środowiska w Polsce (struktura prawna i funkcje), Wrocław 1986, s. 60-65.

31 J. Boć, K. Nowacki, E. Samborski-Boć, Ochrona środowiska..., s. 397; R. Paczuski, Prawo ochrony środowiska..., s. 137; K. Popik-Chorąży, Administracyjna kara pieniężna w ustawie-Prawo ochrony środowiska (w:) J. Stelmasiak (red.), Prawo ochrony środowiska, Warszawa 2009, s. 195; M. Górski, Odpowiedzialność administracyjno-prawna w ochronie środowiska. Zagadnienia podstawowe, Poznań 2007, s. 68-76; A. Barczak, Model gospodarowania odpadami komunalnymi w Polsce i Niemczech. Analiza porównawczo-prawna, Szczecin 2013, s. 340; A. Kudrzycka, Postępowanie administracyjne w sprawie wymierzenia administracyjnej
O odmienności administracyjnych kar pieniężnych od środków stosowanych w prawie karnym przesądza ukształtowanie modelu odpowiedzialności za naruszenie norm obowiązującego porządku prawnego ${ }^{32}$. Warto zasygnalizować, że wskazane w piśmiennictwie cechy ${ }^{33}$ odróżniające odpowiedzialność administracyjną od pozostałych rodzajów odpowiedzialności prawnej charakteryzują również odpowiedzialność za delikty administracyjne. Stanowi to potwierdzenie przyjętego założenia o zaklasyfikowaniu tego typu odpowiedzialności do odpowiedzialności administracyjnej. Co prawda określenie „kara” ${ }^{34}$ podkreśla pewne elementy represji i przymusu, jednak kary wymierzane w jednostkach pieniężnych występują zarówno w prawie karnym, pod nazwą grzywny, jak i w prawie administracyjnym, pod normatywnie

kary pieniężnej w prawie ochrony środowiska, „Przegląd Prawa Ochrony Środowiska” 2014, nr 2, s. 140.

32 K. Popik-Chorąży, Administracyjna kara pieniężna w ustawie-Prawo ochrony środowiska..., s. 195.

33 W publikacji J. Boć, K. Nowacki, E. Samborski-Boć, Ochrona środowiska..., s. 394-396, zaliczono do nich następujące cechy:

- odpowiedzialność administracyjna stanowi element mechanizmu funkcjonowania państwa i administracji publicznej zmierzającego do zastopowania lub zmniejszania zanieczyszczenia środowiska,

- odpowiedzialności administracyjnej opiera się na prawie administracyjnym,

- treść i rozmiar odpowiedzialności określa organ administracji publicznej poprzez wypowiedź o charakterze władczym i swoistym dla administracji,

- realizacja odpowiedzialności administracyjnej poprzez działanie organów publicznych stanowi stały obowiązek administracyjnoprawny uruchamiany z urzędu,

- całość procedury realizacji obowiązku administracyjnoprawnego regulowana jest za pomocą instytucji postępowania administracyjnego,

- ochrona interesu publicznego stanowi istotny element przy realizacji możliwych do przypisania funkcji odpowiedzialności administracyjnej,

- przebieg ustalenia uruchomienia odpowiedzialności administracyjnej jest obiektywny.

34 Kara jest sankcją stosowaną nie tylko w prawie karnym (wyrok Trybunału Konstytucyjnego z dnia 4 lipca 2002 r., P12/01, OTK-A 2002, z. 4, poz. 50). 
określoną nazwą administracyjnej kary pieniężnej ${ }^{35}$. Naliczanie i wymierzanie administracyjnych kar pieniężnych nie jest jednak uzależnione od stwierdzenia winy $^{36}$. Wystarczające jest stwierdzenie samego naruszenia prawa lub ostatecznej decyzji administracyjnej, czyli obiektywnie ujęte bezprawie administracyjne ${ }^{37}$. W rezultacie podmiot odpowiada jedynie za skutek swojego działania, a wskazane obiektywnie ujęte bezprawie administracyjne stanowi kluczowy argument świadczący o zakwalifikowaniu deliktów administracyjnych do odpowiedzialności administracyj$n \mathrm{j}^{38}$. Istotne jest również to, że administracyjne kary pieniężne wymierzane są przede wszystkim innym podmiotom niż osoby fizyczne. W większości przypadków wymierza się je osobom prawnym lub innym jednostkom organizacyjnym. Administracyjne kary pieniężne pełnią przede wszystkim rolę prewencyjną ${ }^{39}$ - są bodźcem zniechęcająco-powstrzymującym od niewykonywania obowiązków. Nie należy natomiast traktować ich jako odszkodowania za szkody środowiskowe, gdyż podmiot, któremu wymierzono karę, nie zostaje zwolniony z odpowiedzialności cywilnej realizowanej na zasadach ogólnych ${ }^{40}$. Warto jednak zauważyć, że towarzyszyć im może również funkcja kompensacyjna. Występuje ona, gdy zostają spełnione

35 W. Fill, Charakter administracyjnych kar pieniężnych (na tle prawa ochrony środowiska), „Państwo i Prawo” 2009, nr 6, s. 63.

36 J. Jendrośka (red.)., Leksykon prawa ochrony środowiska, Warszawa 2012, s. 15.

37 K. Popik-Chorąży, Kara pieniężna w prawie ochrony środowiska, Lublin 2009, s. 40.

38 Według niektórych autorów wymierzanie administracyjnych kar pieniężnych nie stanowi odpowiedzialności obiektywnej. Przykładowo A. Wróbel argumentuje to w następujący sposób. Po pierwsze, organ administracji publicznej może odstąpić od nałożenia administracyjnej kary pieniężnej pomimo stwierdzenia naruszenia prawa, zaś po drugie - przy wymiarze administracyjnej kary pieniężnej uwzględnia się wymienione w komentowanym przepisie okoliczności wpływające na jej wysokość. Zob. A. Wróbel (w:) M. Jaśkowska, M. Wildbrandt-Gotowicz, A. Wróbel, Kodeks postępowania administracyjnego. Komentarz, Warszawa 2020, dostęp LEX.

39 M. Górski, Odpowiedzialność administracyjnoprawna w ochronie środowiska, Warszawa 2008, s. 103.

40 Szerzej: M. Górski, Odpowiedzialność administracyjno-prawna w ochronie środowiska. Zagadnienia podstawowe..., s. 68-69. dwa warunki. Pierwszym z nich jest wykazanie, że naliczenie i wymierzenie kary oraz jej wysokość pozostają w związku ze szkodą. Po drugie, środki finansowe uzyskane z takich kar powinny być wykorzystane do likwidacji szkód spowodowanych niewykonaniem obowiązków albo do przeciwdziałaniu powstawaniu takich szkód (przynajmniej częściowo) ${ }^{41}$. Z kolei funkcja represyjna służy zabezpieczeniu wykonywania obowiązków, jednak nie jest ona jedynym powodem wymierzenia administracyjnej kary pieniężnej.

Na uwagę zasługują także dyrektywy wymiaru administracyjnej kary pieniężnej określone w art. 189d k.p.a. Nie znajdują one jednak zastosowania w przypadku kar nakładanych decyzjami związanymi ${ }^{42}$. Organ administracji publicznej, dokonując wymierzenia administracyjnej kary pieniężnej, bierze pod uwagę:

- wagę i okoliczności naruszenia prawa, w szczególności potrzebę ochrony życia lub zdrowia, ochrony mienia w znacznych rozmiarach lub ochrony ważnego interesu publicznego lub wyjątkowo ważnego interesu strony oraz czas trwania tego naruszenia,

- częstotliwość niedopełniania w przeszłości obowiązku albo naruszania zakazu tego samego rodzaju co niedopełnienie obowiązku albo naruszenie zakazu, w następstwie którego ma być nałożona kara,

- uprzednie ukaranie za to samo zachowanie za przestępstwo, przestępstwo skarbowe, wykroczenie lub wykroczenie skarbowe,

- stopień przyczynienia się strony, na którą jest nakładana administracyjna kara pieniężna, do powstania naruszenia prawa,

- działania podjęte przez stronę dobrowolnie w celu uniknięcia skutków naruszenia prawa,

- wysokość korzyści, którą strona osiągnęła, lub straty, której uniknęła,

- w przypadku osoby fizycznej - warunki osobiste strony, na którą administracyjna kara pieniężna jest nakładana.

41 K. Popik-Chorąży, Administracyjna kara pieniężna w ustawie-Prawo ochrony środowiska..., s. 205.

42 Szerzej: wyrok Wojewódzkiego Sądu Administracyjnego w Warszawie z dnia 11 lipca 2018 r., VIII SA/Wa 205/18, LEX nr 2531534. 
Swoboda dyrektora urzędu morskiego jest zatem istotnie ograniczona. Po pierwsze poprzez ustawowe granice wysokości administracyjnej kary pieniężnej, a po drugie poprzez kodeksowe dyrektywy wymiaru tej kary. Co istotne, wśród dyrektyw wymiaru kary pieniężnej nie wskazano dyrektywy nieprzekraczania stopnia winy. W ujęciu k.p.a. wina nie przesądza zatem kary pieniężne jako swoistą formę odpowiedzialności administracyjnej. Warto także odwołać się do stanowiska zajętego przez Wojciecha Filla, zgodnie z którym instytucja administracyjnych kar pieniężnych ze względu na ich kompleksowy charakter jest zagadnieniem interdyscyplinarnym ${ }^{46}$. Niektórzy autorzy przypisują administracyjnym karom pieniężnym

\section{Przepisy prawne w zakresie zapobiegania} zanieczyszczaniu morza przez statki wprowadzają system administracyjnych kar pieniężnych wymierzanych przez dyrektorów urzędów morskich w formie decyzji administracyjnych.

o wysokości wymierzanej administracyjnej kary pieniężnej. Oznacza to, że odpowiedzialność prawna za naruszenie, w następstwie którego wymierzana jest administracyjna kara pieniężna, nie jest odpowiedzialnością opartą na zasadzie winy.

Delikty administracyjne stanowią przejaw odpowiedzialności administracyjnej. Nie wszyscy autorzy podzielają jednak pogląd przyporządkowujący ten instrument do odpowiedzialności administracyjnej. Tytułem przykładu należy wskazać na traktowanie deliktów administracyjnych jako odrębnego rodzaju odpowiedzialności karnej przez Jana Jerzmańskiego oraz Wojciecha Radeckiego ${ }^{43}$. Wskazani autorzy uznają je za prawo karne środowiska sensu largissimo $^{44}$. Początkowo jednak zarówno W. Radecki, jak i J. Jerzmański ${ }^{45}$ traktowali administracyjne

43 Szerzej: J. Jerzmański, Odpowiedzialność administracyjna (w:) Instytucje prawa ochrony środowiska..., s. 401; W. Radecki, Odpowiedzialność karna (w:) Instytucje prawa ochrony środowiska..., s. 425-456.

44 W. Radecki, Opłaty i kary pieniężne w ochronie środowiska..., s. 38 .

45 W. Radecki, Odpowiedzialność administracyjna w ochronie środowiska..., s. 114; H. Lisicka, I. Macek, W. Radecki, Lek- nawet rolę systemową, gdyż odpowiedzialność administracyjna zaczyna przejmować funkcję odpowiedzialności karnej ${ }^{47}$.

\section{Administracyjne kary pieniężne} nakładane na armatorów jako instrument odpowiedzialności administracyjnej za zanieczyszczanie wód morskich przez statki

Przepisy prawne w zakresie zapobiegania zanieczyszczaniu morza przez statki wprowadzają system administracyjnych kar pieniężnych wymierzanych przez dyrektorów urzędów morskich w formie decyzji administracyjnych ${ }^{48}$. Wyróżnić należy podmioty odpowiedzialne, do których zalicza się: armatora

sykon ochrony środowiska. Prawo i polityka, Wrocław 1999, s. 122 .

46 W. Fill, Charakter administracyjnych kar pieniężnych..., s. 74 .

47 D.K. Nowicki, S. Peszkowski, Kilka uwag o szczególnym charakterze administracyjnych kar pieniężnych (w:) M. Błachucki (red.), Administracyjne kary pieniężne $w$ demokratycznym państwie prawa, Warszawa 2015, s. 11.

48 J. Ciechanowicz-McLean, Ochrona środowiska morskiego, "Prace Naukowe Uniwersytetu Śląskiego” 2000, nr 1871, s. 202-203. 
statku, załadowcę, dostawcę paliwa żeglugowego, kapitana statku albo innego członka załogi. Warto zatem zauważyć, że wymienione podmioty nie zawsze należą do kategorii osób fizycznych. W konsekwencji jedna z podstawowych cech odpowiedzialności administracyjnej w postaci ponoszenia jej również przez osoby prawne i jednostki organizacyjne ${ }^{49}$ jest widoczna $\mathrm{w}$ analizowanym przypadku.
Podmiotem odpowiedzialnym za największą ilość deliktów administracyjnych w zakresie zanieczyszczania wód morskich jest armator. Zgodnie z art. 7 ustawy z dnia 18 września 2001 r. Kodeks morski ${ }^{52}$ armatorem jest ten, kto we własnym imieniu uprawia żeglugę statkiem morskim własnym lub cudzym. W art. 4 pkt 2 u.z.z.m.s. wprowadzono do wskazanej definicji uzupełnienie wynikające $\mathrm{z}$ cha-

\section{Oprócz odpowiedzialności cywilnej armator} ponosi odpowiedzialność administracyjną

\section{za naruszenie przez statek przepisów o charakterze publicznoprawnym z zakresu ochrony środowiska.}

Wspólną cechą wszystkich analizowanych poniżej deliktów administracyjnych jest wymierzanie kary w jednostkach obliczeniowych zwanych Specjalnym Prawem Ciągnienia (Special Drawing Right - SDR). SDR-y zostały utworzone w celu stabilizacji międzynarodowego systemu walutowego przez Międzynarodowy Fundusz Walutowy w 1967 r., natomiast w 1970 r. wprowadzono je jako narzędzie w walce $z$ grożącym kryzysem płynności ${ }^{50}$. Jest to pieniądz wyłącznie rozrachunkowy, mający charakter pieniądza bezgotówkowego, czyli istniejącego wyłącznie w postaci zapisów księgowych na bankowych rachunkach depozytowych ${ }^{51}$.

Wysokość kar pieniężnych każdorazowo ustalana jest z uwzględnieniem zakresu naruszeń, korzyści finansowych uzyskanych z tytułu naruszeń i powtarzalności naruszeń. Odnosząc się do nieostrego terminu „Zakres naruszeń”, należy wskazać, że uzależniony jest od poszczególnych deliktów administracyjnych.

\footnotetext{
49 J. Jerzmański, Odpowiedzialność administracyjna (w:) Instytucje prawa ochrony środowiska..., s. 400.

50 https://www.nbportal.pl/wiedza/artykuly/pieniadz/kilka-slow-na-temat-sdr-chin-oraz-keynesa (dostęp 10.03.2018)

51 Tamże.
}

rakteru regulacji. Doprecyzowano, że jest to osoba prowadząca działalność w środowisku morskim, czyli eksploatująca statek dla różnych celów (gospodarczych, sportowych, naukowych itd.). W konsekwencji armator nie zawsze jest właścicielem statku, ponieważ można być armatorem statku własnego (posiadacz samoistny) lub cudzego (posiadacz zależny) ${ }^{53}$. Ze względu na oddzielenie własności od eksploatacji to właśnie armator jest centralną postacią w polskim prawie morskim ${ }^{54}$. To on jest podmiotem praw i obowiązków związanych z żeglugą w środowisku morskim. Oprócz odpowiedzialności cywilnej armator ponosi również odpowiedzialność administracyjną za naruszenie przez statek przepisów o charakterze publicznoprawnym z zakresu ochrony środowiska. Zasygnalizować należy, że w zakresie zapobiegania zanieczyszczaniu morza przez statki armator ponosi odpowiedzialność administracyjną wyłącznie na podstawie przepisów u.z.z.m.s. ${ }^{55}$ Co istotne, przepis art. 55 ust. 1 ustawy z dnia 21 marca 1991 r. o obsza-

\footnotetext{
52 T.j. Dz.U. 2018, poz. 2175 ze zm.

53 J. Młynarczyk, Prawo morskie, Gdańsk 2002, s. 90.

54 J. Łopuski (w:) Prawo morskie, t. 1, Bydgoszcz 1996, s. $246-249$.

55 Art. 55 ust. 2 u.o.m.
} 
rach morskich Rzeczypospolitej Polskiej i administracji morskiej ${ }^{56}$ nie znajduje w tym przypadku zastosowania, gdyż dotyczy on zanieczyszczeń innych niż te pochodzące ze statków.

Zaprezentowane poniżej delikty administracyjne dotyczą zanieczyszczania środowiska morskiego, a zatem także zanieczyszczania wód morskich, będącego przedmiotem zainteresowania niniejszych rozważań. Pierwszym z deliktów jest bezprawne, naruszające przepisy u.z.z.m.s. zanieczyszczenie środowiska morskiego, w związku z eksploatacją statku lub zatopieniem w morzu odpadów i innych substancji ${ }^{57}$. W tym przypadku odpowiedzialność ponosi armator, z którego statku podczas przebywania w polskich obszarach morskich dokonano wspomnianego zanieczyszczenia. Drugim deliktem administracyjnym, za który odpowiedzialność ponosi armator statku o polskiej przynależności, jest bezprawne zanieczyszczenie środowiska morskiego poza polskimi obszarami morskimi dokonywane w związku z eksploatacją statku lub zatopieniem w morzu odpadów albo innych substancji ${ }^{58}$. Przesłanką odpowiedzialności jest w tym przypadku działanie bez wymaganego zezwolenia lub wbrew jego warunkom. W rezultacie armator odpowiada zarówno jeżeli do zanieczyszczenia doszło w polskich obszarach morskich, bez względu na przynależność statku, jak i w środowisku morskim poza polskimi obszarami morskimi, jeżeli naruszenia dokonuje statek o polskiej przynależności ${ }^{59}$. Wskazane rozróżnienie dwóch wymienionych deliktów stanowi konsekwencję aktualnego zakresu zastosowania przepisów u.z.z.m.s. Co istotne, za wskazane czyny ustawodawca przewidział jednakowe sankcje w postaci kary pieniężnej o równowartości do 1000000 SDR. Przywołane powyżej regulacje prawne należy ocenić pozytywnie przede wszystkim ze względu na uniezależnienie odpowiedzialności z tytułu deliktów od negatywnych konsekwencji zanieczyszczeń. Samo wystąpienie zagrożenia jest wystarczającym powodem uzasadniającym odpowiedzialność prawną w tym przypadku. W rezultacie

56 T.j. Dz.U. 2019, poz. 2169 ze zm. (dalej: u.o.m.)

57 Art. 36 ust. 1 u.z.z.m.s.

58 Art. 36 ust. 2 u.z.z.m.s.

59 W. Radecki, Odpowiedzialność prawna w ochronie środowiska, Warszawa 2002, s. 265-266. pogorszenie jakości wody spowodowanie zniszczenia fauny i flory morskiej lub zagrożenie zdrowiu lub życiu ludzi w określonej skali nie jest warunkiem sine qua non pociągnięcia armatora do odpowiedzialności za powyższe czyny. Kara pieniężna o równowartości do 1000000 SDR jest karą niezwykle restrykcyjną, przez co może skutecznie pełnić funkcje jej przypisane. Nie należy bowiem zapominać, że ważną funkcję administracyjnych kar pieniężnych w systemie ochronnym wód morskich stanowi funkcja prewencyjna polegająca na powstrzymywaniu przed dokonaniem naruszenia prawa ${ }^{60}$. Surowe kary pieniężne są dodatkowo uzasadnione ze względu na wysokie koszty naprawienia szkód w środowisku morskim. Wypada zaznaczyć, że u.z.z.m.s. określa jedynie górną granicę kary, natomiast kara rzeczywiście wymierzona ma charakter względny, gdyż jej wysokość ustalana jest z uwzględnieniem zakresu naruszeń, korzyści finansowych uzyskanych z tytułu naruszeń i powtarzalności naruszeń ${ }^{61}$. Ponadto armator będący osobą fizyczną nie ponosi odpowiedzialności administracyjnej za pierwszy z wymienionych deliktów administracyjnych, jeżeli jego zachowanie realizuje jednocześnie znamiona przestępstwa określonego $\mathrm{w}$ art. 35a u.z.z.m.s. (usuwanie substancji objętych załącznikami 1 i 2 do Konwencji Marpol wywierające negatywny wpływ na środowisko morskie i przebywające w nim osoby), a przestępstwo to zostało stwierdzone prawomocnym wyrokiem skazującym.

Kolejne delikty administracyjne obciążające armatora statku związane z niewykonywaniem ciążących na nim obowiązków lub łamaniem ustanowionych prawem zakazów można sklasyfikować w zależności od źródła zanieczyszczenia. Za analizowane poniżej czyny ustawodawca przewidział jednakowe sankcje w postaci kary pieniężnej o równowartości do 50000 SDR $^{62}$.

W odniesieniu do zanieczyszczeń spowodowanych przewożonymi ładunkami wyróżnić należy delikt

60 J. Cheda, Zapobieganie zanieczyszczeniu morza przez statki (w:) P. Korzeniowski (red.), Prawa i obowiązki przedsiębiorców w ochronie środowiska. Zarys encyklopedyczny, Warszawa 2010 , s. 373

61 Art. 36 ust. 1 u.z.z.m.s.

62 Art. 36a i art. 36aa u.z.z.m.s. 
administracyjny w postaci przewozu ładunków niebezpiecznych lub zanieczyszczających bez przekazania dyrektorowi urzędu morskiego informacji o rodzaju przewożonego ładunku, zamierzonej trasie, czasie podróży oraz stanie bezpieczeństwa statku ${ }^{63}$.

Z kolei w odniesieniu do zanieczyszczeń spowodowanych szkodliwymi systemami przeciwporostowymi wyróżnić należy następujące delikty administracyjne:

- stosowanie lub ponowne stosowanie na statku związków cynoorganicznych, które działają jak biocydy,

- eksploatowanie statku, na którego kadłubie występują związki cynoorganiczne,

- eksploatowanie statku, z którego emitowane są do powietrza substancje zubożające warstwę ozonową, tlenki azotu lub fluorowane gazy cieplarniane $^{64}$.

Nawiązując do pośredniego zanieczyszczania wód morskich poprzez powietrze atmosferyczne - powinno się zwrócić uwagę na następujące delikty administracyjne:

- dopuszczenie osoby nieposiadającej odpowiednich uprawnień (osoba posiadająca co najmniej stopień oficera mechanika wachtowego, osoba posiadająca stosowny certyfikat dla personelu albo przedsiębiorca zatrudniający taką osobę) do wykonywania odzysku substancji kontrolowanych lub fluorowanych gazów cieplarnianych z urządzeń chłodniczych, klimatyzacyjnych, rozdzielnic elektrycznych oraz systemów ochrony przeciwpożarowej i gaśnic w celu zapewnienia ich regeneracji, recyklingu lub zniszczenia,

- niewypełnienie obowiązku przekazania w terminie rocznych sprawozdań dotyczących substancji zubożających warstwę ozonową lub fluorowanych gazów cieplarnianych przywożonych na terytorium Rzeczpospolitej Polskiej oraz wywożonych z tego terytorium do wyspecjalizowanej jednostki prowadzącej bazę danych,

- niepodejmowanie wszelkich wykonalnych środków ostrożności w celu zapobiegania wszelkim wyciekom i emisjom substancji kontrolowanych

63 Art. 36a pkt 1 u.z.z.m.s.

64 Art. 36a pkt 7-9 u.z.z.m.s. i fluorowanych gazów cieplarnianych oraz ich minimalizowania,

- użytkowanie instalacji lub urządzeń zawierających substancje kontrolowane w sposób niezapobiegający emisji substancji kontrolowanych do środowiska oraz nieprzeprowadzanie sprawdzenia szczelności tych urządzeń ${ }^{65}$.

Ponadto w zakresie pośredniego zanieczyszczania wód morskich poprzez powietrze atmosferyczne wyróżnić należy jeszcze inne delikty administracyjne. Zwrócenia uwagi wymaga przede wszystkim delikt administracyjny w postaci używania na statku paliwa żeglugowego zawierającego niedopuszczalną zawartość siarki ${ }^{66}$. W przypadku tego deliktu ustawodawca przewidział dwie przesłanki wyłączające odpowiedzialnośćc7. Pierwszą z nich jest zastosowanie przez armatora statku zatwierdzonych metod redukcji emisji dwutlenku węgla oraz metod redukcji siarki. Druga natomiast zostaje zrealizowana poprzez przedstawienie dowodu w postaci pisemnego oświadczenia dostawcy paliwa o braku dostępności paliwa w danym porcie, wykazującego niemożliwość nabycia paliwa żeglugowego o zawartości siarki dopuszczalnej na danym obszarze morskim. Kolejnym deliktem jest delikt administracyjny w postaci stosowania na statku niezatwierdzonych metod redukcji emisji ${ }^{68}$. W obu wskazanych przypadkach armator podlega karze pieniężnej do wysokości 600000 SDR. Z kolei zachowanie armatora polegające na nieprzekazaniu wyników testów metod redukcji emisji dyrektorowi urzędu morskiego jest deliktem administracyjnym zagrożonym karą pieniężną do wysokości 100000 SDR $^{69}$.

Nie ulega wątpliwości, że w przypadku statków objętych specyficznym reżimem prawnym zakres zachowań skutkujących pociągnięciem do odpowiedzialności jest szerszy. W przypadku armatorów statków, do których zastosowanie znajdują przepisy rozporządzenia Parlamentu Europejskiego i Rady (UE) 2015/757 z dnia 29 kwietnia 2015 r. w sprawie monitorowania, raportowania i weryfikacji emisji dwutlenku węgla z trans-

\footnotetext{
65 Art. 36a pkt 2-6 u.z.z.m.s

66 Art. 36aa ust. 1 u.z.z.m.s.

67 Art. 38 ust. 3 u.z.z.m.s.

68 Art. 36aa ust. 2 u.z.z.m.s.

69 Art. 36aa ust. 3 u.z.z.m.s.
} 
portu morskiego oraz zmiany dyrektywy 2009/16/ $\mathrm{WE}^{70}$, do zachowań podlegających ujemnej kwalifikacji normatywnej zalicza się dodatkowo:

- niemonitorowanie emisji dwutlenku węgla z każdego statku w odniesieniu do każdego rejsu, w rocznych okresach przy zastosowaniu odpowiedniej metody,

- niemonitorowanie w sposób określony obowiązującym prawem parametrów ${ }^{71}$,

- nieprzedłożenie Komisji Europejskiej lub dyrektorowi urzędu morskiego właściwemu dla portu macierzystego statku raportu emisji w terminie do 30 kwietnia każdego roku,

- niezapewnienie, aby w przypadku zmiany podmiotu zarządzającego statkiem każdy statek spełniał wymogi rozporządzenia 2015/757 w odniesieniu do całego okresu sprawozdawczego, w którym podmiot zarządzający statkiem odpowiada za dany statek,

- niezłożenie raportu emisji z wykorzystaniem automatycznych systemów i formatów wymiany danych, w tym szablonów elektronicznych ${ }^{72}$.

Powyżej wskazane delikty administracyjne podlegają karze pieniężnej do wysokości $50000 \mathrm{SDR}^{73}$.

Właściwość organów oraz tryb wymierzania i egzekwowania analizowanych powyżej kar pieniężnych określają przepisy u.o.m. Administracyjne kary pieniężne wymierza dyrektor urzędu morskiego w dro-

70 Dz.Urz.UE.L 123 z 19 maja 2015 r., s. 55, dalej: rozporządzenie 2015/757. Chodzi o statki o pojemności brutto powyżej 5000 jednostek w odniesieniu do emisji dwutlenku węgla uwalnianych przez te statki w trakcie ich rejsów z ostatniego portu zawinięcia do portu zawinięcia podlegającego jurysdykcji państwa członkowskiego oraz rejsów z portu zawinięcia podlegającego jurysdykcji państwa członkowskiego do następnego portu zawinięcia, jak również w obrębie portu zawinięcia podlegającego jurysdykcji państwa członkowskiego.

71 Chodzi o parametry emisyjne, port wyjścia i port przybycia, łącznie z datą i godziną wyjścia z portu i przybycia do portu, zużycie i współczynnik emisji dla wszystkich rodzajów zużytego paliwa łącznie, wyemitowany dwutlenek węgla, przebytą odległość, czas spędzony na morzu, przewożony ładunek oraz wykonaną pracę transportową.

72 Art. 2 rozporządzenia 2015/757.

73 Art. 36 aa ust. 5 u.z.z.m.s. dze decyzji administracyjnej. Decyzji tej nadaje się rygor natychmiastowej wykonalności ${ }^{74}$, co oznacza, że decyzja w sprawie nałożenia administracyjnej kary pieniężnej jest wykonalna przed upływem terminu do wniesienia od niej odwołania. Rygor natychmiastowej wykonalności wygaśnie z chwilą wydania przez organ odwoławczy decyzji zmieniającej lub uchylającej decyzję, w której zawarty był rygor natychmiastowej wykonalności. Decyzja administracyjna o nałożeniu administracyjnej kary pieniężnej, będąca aktem administracyjnym $^{75}$ o charakterze restrykcyjnym ${ }^{76}$, jest środkiem służącym realizacji odpowiedzialności administracyjnej. Administracyjne kary pieniężne nakładane są w drodze decyzji administracyjnej związanej. Oznacza to, że dyrektor urzędu morskiego ma obowiązek jej wymierzenia w przypadku stwierdzenia znamion deliktów administracyjnych. Kara ta ma zatem charakter obligatoryjny. Co istotne, dyrektor urzędu morskiego został zobowiązany do ustalania wysokości kar pieniężnych, z uwzględnieniem zakresu naruszenia, powtarzalności naruszeń lub korzyści finansowych uzyskanych z tytułu naruszenia ${ }^{77}$. Wprowadzając przedmiotowe rozwiązanie ustawodawca zbliża odpowiedzialność za delikty administracyjne do odpowiedzialności karnej ${ }^{78}$.

Od decyzji o nałożeniu administracyjnej kary pieniężnej wydawanej przez dyrektora urzędu morskiego przysługuje odwołanie do ministra właściwego do spraw gospodarki morskiej ${ }^{79}$. Następnie można wnieść skargę do sądu administracyjnego na zasadach ogólnych $^{80}$. Wskazać należy, że przesłanką wyłączającą wymierzenie administracyjnych kar pieniężnych z tytułu deliktów administracyjnych jest upływ pięciu lat od dnia popełnienia czynu ${ }^{81}$. Jednocześnie

74 Art. 57 ust. 3 u.o.m.

75 Szerzej: K. Popik-Chorąży, Administracyjna kara pieniężna w ustawie-Prawo ochrony środowiska..., s. 199.

76 K. Popik-Chorąży, Kara pieniężna..., s. 43.

77 Art. 38 ust. 2 u.z.z.m.s.

78 W. Radecki, Odpowiedzialność karna (w:) Instytucje prawa ochrony środowiska..., s. 447.

79 Według zasad wynikających z k.p.a. oraz z ustawy z dnia 30 sierpnia 2002 r. Prawo o postępowaniu przed sądami administracyjnymi, t.j. Dz.U. 2019, poz. 2325 ze zm.

80 K. Popik-Chorąży, Kara pieniężna..., s. 104.

81 Art. 58 ust. 1 u.o.m. 
wymierzonej kary pieniężnej nie pobiera się po upływie pięciu lat od daty wydania ostatecznej decyzji o nałożeniu kary ${ }^{82}$.

Dyrektor urzędu morskiego został upoważniony do zażądania od sprawcy zabezpieczenia należności w celu zabezpieczenia ściągalności kary pieniężnej. W razie odmowy zabezpieczenia należności organ ten został zobowiązany do wystąpienia do organu egzekucyjnego o zajęcie statku lub innych przedmiotów, za pomocą których dokonano naruszenia przepisów chroniących wody morskie przed zanieczyszczeniami ze statków. Do czasu wydania postanowienia o zajęciu statku dyrektor urzędu morskiego został upoważniony do zarządzenia zatrzymania statku, nie dłużej jednak niż na $48 \operatorname{godzin}^{83}$. W tym przypadku jest to przykład kompetencji połączonej z obowiązkiem czynienia z niej użytku. Zabezpieczenie ściągalności kary pieniężnej polega na wpłaceniu określonej przez organ prowadzący postępowanie kwoty pieniężnej do depozytu tego organu lub złożeniu gwarancji bankowej przez bank albo gwarancji ubezpieczeniowej przez zakład ubezpieczeń mający siedzibę w Polsce ${ }^{84}$. Kary ustalone, a nieuiszczone w wyznaczonym terminie wraz z odsetkami za zwłokę podlegają ściągnięciu $\mathrm{w}$ trybie określonym w przepisach o postępowaniu egzekucyjnym w administracji i stają się dochodami budżetu państwa ${ }^{85}$.

Wymierzanie kar pieniężnych w drodze postępowania administracyjnego należy ocenić pozytywnie ze względu na brak konieczności uczestniczenia w postępowaniu sądowym, które często jest długotrwałe. W literaturze pojawiają się jednak również głosy krytycznie odnoszące się do obecnych regulacji prawnych. Przykładowo W. Radecki negatywnie ocenia odstąpienie od stosowania reguł odpowiedzialności karnej przed sądami powszechnymi ze względu na brak gwarancji przysługujących podmiotom w postępowaniu w sprawach o wykroczenia oraz brak kontroli sądów powszechnych $^{86}$. Należy jednak podkreślić, że decyzje

82 Art. 58 ust. 2 u.o.m.

83 Art. 59 ust. 1 i 2 u.o.m.

84 Art. 59 ust. 3 u.o.m.

85 Art. 59 ust. 4 u.o.m.

86 W. Radecki, Odpowiedzialność prawna w ochronie środowiska, Warszawa 2002, s. 265-266. nakładające administracyjne kary pieniężne podlegają kontroli sądów administracyjnych. Ponadto toczące się w tych sprawach postępowanie jest dwuinstancyjne, co pozwala stronie niezadowolonej z decyzji dyrektora urzędu morskiego jako organu pierwszej instancji, wymierzającej administracyjną karę pieniężną, wnieść środek odwoławczy do ministra właściwego do spraw gospodarki morskiej, jako organu drugiej instancji. Należy podkreślić, że decyzje nakładające kary pieniężne mają charakter decyzji związanych. $\mathrm{Na}$ aprobatę zasługuje również zunifikowanie zasad wymiaru administracyjnej kary pieniężnej w postaci wskazania trzech okoliczności, które powinny być brane pod uwagę przez dyrektora urzędu morskiego przy dokonywaniu wymiaru kary.

Dodatkowo uniezależnienie odpowiedzialności od winy znacznie ułatwia wykazanie przesłanek pociągnięcia do odpowiedzialności i ukaranie sprawcy naruszenia, co jest korzystne z punktu widzenia ochrony wód morskich. W doktrynie prawa ochrony środowiska wysunięty został postulat de lege ferenda w postaci wprowadzenia do prawa ochrony środowiska subiektywnego elementu zawinienia w odniesieniu do administracyjnych kar pieniężnych ${ }^{87}$. Ma się to sprowadzać do przeprowadzenia dowodu, że ukarany uczynił wszystko, czego można było od niego rozsądnie wymagać, aby do przekroczenia lub naruszenia nie doszło ${ }^{88}$. Warto zasygnalizować, że postulat wprowadzenia elementu zawinienia znalazł zastosowanie przykładowo w przypadku odpowiedzialności za szkodę w gatunkach chronionych lub chronionych siedliskach przyrodniczych ${ }^{89}$.

W przypadku ochrony wód morskich, ze względu na potencjalne skutki zanieczyszczania mórz, postulat wprowadzenia subiektywnego elementu zawinienia należy ocenić krytycznie. W regulacjach służących ochronie wód morskich instytucja tego rodzaju nie powinna być stosowana. Jedyny wyjątek może stanowić wprowadzenie instytucji ekskulpacji w przy-

87 W. Radecki (w:) M. Górski i in., Prawo ochrony środowiska. Komentarz, Warszawa 2014, s. 817.

88 Tamże.

89 Por. w art. 2 ust. 1 pkt 2 ustawy z dnia z dnia 13 kwietnia 2007 r. o zapobieganiu szkodom w środowisku i ich naprawie (t.j. Dz.U. 2019, poz. 1862 ze zm.). 
padku popełnienia deliktu z przyczyn spowodowanych siłą wyższą. W innych przypadkach nie dochodzi bowiem do stawiania armatora w nadmiernie niekorzystnej dla niego sytuacji. Ponoszący odpowiedzialność obiektywną armator może bowiem żądać naprawienia szkody od podmiotu za nią odpowiedzialnego w drodze postępowania cywilnego.

Biorąc pod uwagę powyżej przywoływane regulacje prawne dotyczące odpowiedzialności prawnej armatorów statków za zanieczyszczenie wód morskich, należy stwierdzić, że jest ona dotkliwa dla tych podmiotów ${ }^{90}$. Na wniosek taki wpływa przede wszystkim wysokość stosowanych kar oraz tryb ich nakładania w postaci decyzji administracyjnej z klauzulą natychmiastowej wykonalności, wydawanej przez dyrektora urzędu morskiego. Nie bez znaczenia pozostaje także szeroki zakres uprawnień i kompetencji przyznanych dyrektorom urzędów morskich, który oddziałuje na sytuację armatorów. Podkreślić należy również, że żaden przepis prawa materialnego nie wskazuje winy jako przesłanki pociągnięcia armatora do odpowiedzial- odpowiedzialności za delikty administracyjne jako odpowiedzialności obiektywnej, czyli odpowiedzialności administracyjnej, a nie karnej.

\section{Administracyjne kary pieniężne} nakładane na pozostałe podmioty jako instrument odpowiedzialności administracyjnej za zanieczyszczanie wód morskich przez statki

Odpowiedzialność administracyjną w postaci administracyjnych kar pieniężnych ponoszą również inne podmioty niż armator. Wskazać należy przede wszystkim na kapitana statku lub innego członka załogi statku $^{92}$. Podmioty te w sytuacji niewykonania ciążących na nich z mocy prawa obowiązków podlegają karze pieniężnej do wysokości nieprzekraczającej dwudziestokrotnego przeciętnego miesięcznego wynagrodzenia w gospodarce narodowej za rok poprzedzający, ogłaszanego przez Prezesa Głównego Urzędu Statystycznego ${ }^{93}$. Wyróżnić należy w tym zakresie następujące delikty administracyjne:

\section{W przypadku ochrony wód morskich, ze względu} na potencjalne skutki zanieczyszczania mórz, postulat wprowadzenia subiektywnego elementu zawinienia należy ocenić krytycznie.

ności za delikt administracyjny. Dlatego też o odpowiedzialności przesądza już samo naruszenie prawa, bez względu na przyczynę sprawczą zanieczyszczenia dokonanego przez statek ${ }^{91}$. Jednocześnie żaden przepis prawa nie wprowadza sformułowania „chociażby nieumyślnie”, co należy uznać na dowód traktowania

90 Por. W. Radecki, Kary pieniężne w ochronie środowiska, Bydgoszcz 1996, s. 86-88; W. Radecki, Kary pieniężne w polskim systemie prawnym czy nowy rodzaj odpowiedzialności karnej, „Przegląd Prawa Karnego” 1996, nr 14-15, s. 14.

91 H. Gotkowicz-Lipowska, Zanieczyszczenia mórz i oceanów. Zanieczyszczenie morza przez statki - obowiąujące regulacje prawne, Szczecin 2003, s. 42.
- brak dbałości o zdatność statku do żeglugi lub innej działalności na morzu w zakresie zapobiegania zanieczyszczaniu morza,

- nieprowadzenie w sposób zgodny z wymogami Konwencji Marpol książki zapisów olejowych,

92 Por. K. Popik-Chorąży, Kara pieniężna..., s. 103-104; R. Paczuski, Prawo ochrony środowiska..., s. 313; B. Bomanowski, T. Piotrowski, Zarys prawnej ochrony przyrody Morza Bałtyckiego przed zanieczyszczeniami ze statków w kontekście interesów podmiotów gospodarujących na Morzu Bałtyckim (w:) M. Górski (red.), Prawo ochrony przyrody a wolność gospodarcza, Poznań 2011, s. 55.

93 Art. 37 u.z.z.m.s. 
ładunkowych, odpadów powstających na statku oraz zapisów o każdorazowym przejściu na zasilanie paliwem innym niż aktualnie używane,

- niezgłoszenie statku do przeglądu lub inspekcji, utrudnianie lub uniemożliwianie przeglądu lub inspekcji w zakresie przewidzianym w Konwencji Marpol,

- spowodowanie zanieczyszczenia środowiska morskiego (w tym wód morskich),

- nieprzekazanie informacji o zauważonym zanieczyszczeniu albo informacji o wypadku zagrożenia zanieczyszczeniem lub zanieczyszczenia środowiska morskiego (w tym wód morskich),

- niepodjęcie koniecznych środków w celu zapobiegania zanieczyszczaniu, ograniczenia lub usunięcia zanieczyszczenia środowiska morskiego (w tym wód morskich), będącego skutkiem wypadku,

- nieprzekazanie, na żądanie właściwych organów, informacji w razie uzasadnionego podejrzenia, że statek, płynąc przez te obszary, naruszył wymagania ochronne, powodując zanieczyszczenie lub zagrożenie zanieczyszczeniem,

- naruszenie przepisów dotyczących zdawania odpadów do portowych urządzeń odbiorczych i niepoinformowanie portu o odpadach ze statków znajdujących się na statku lub o pozostałościach ładunkowych,

- niezgłoszenie organom inspekcyjnym zdarzeń wpływających poważnie na stan techniczny statku, jego urządzeń lub wyposażenia, powodujących zagrożenie dla środowiska morskiego (w tym wód morskich),

- naruszenie przepisów dotyczących spalania odpadów na statku,

- niewykonanie obowiązków w zakresie oznakowania, zakładania i prowadzenia karty urządzenia, sprawdzania szczelności, obsługi i naprawy urządzeń lub instalacji zawierających czynnik chłodniczy będący substancją kontrolowaną,

- nieposiadanie dla statku dokumentów dostawy paliwa żeglugowego znajdującego się w zbiornikach paliwowych statku lub niezawarcie w nich wszystkich wymaganych informacji zgodnie $\mathrm{z}$ konwencją Marpol,

- nieposiadanie na statku próbek paliwa żeglugowego znajdującego się w zbiornikach paliwo- wych statku lub niedopilnowanie ich należytego stanu (niezaplombowanie lub niepodpisanie próbek),

- nieposiadanie następujących dokumentów: wykazu działań podjętych w celu osiągnięcia zgodności z wymaganiami dotyczącymi zawartości siarki w paliwie żeglugowym na danym obszarze morskim oraz dowodu, że podjęto próbę nabycia paliwa żeglugowego o zawartości siarki dopuszczalnej na danym obszarze morskim zgodnie z planem podróży oraz - jeżeli paliwo to nie było dostępne w miejscu, w którym zaplanowano jego nabycie - że podjęto próbę zlokalizowania alternatywnych źródeł takiego paliwa, a także że pomimo podjęcia tych prób nabycie takiego paliwa nie było możliwe,

- nieposiadanie ważnego pozwolenia na przeprowadzanie testów metod redukcji emisji lub niespełnienie warunków przesądzających do dopuszczalności przeprowadzania testów metod redukcji emisji,

- stosowanie na statku metody redukcji emisji w sposób, który nie zapewnia redukcji emisji,

- niedokonanie przejścia na paliwo wymagane na danym obszarze morskim w czasie, który zapewnia spełnienie wymogów dotyczących zawartości siarki w paliwie żeglugowym,

- odmowa pobrania próbek paliwa żeglugowego podczas czynności inspekcyjnych ${ }^{94}$.

Kapitan, podobnie jak armator, nie ponosi odpowiedzialności administracyjnej za delikt administracyjny polegający na spowodowaniu zanieczyszczenia środowiska morskiego (w tym wód morskich), jeżeli jego zachowanie realizuje jednocześnie znamiona przestępstwa określonego $\mathrm{w}$ art. 35a u.z.z.m.s. (usuwanie substancji objętych załącznikami 1 i 2 do Konwencji Marpol wywierające negatywny wpływ na środowisko morskie i przebywające w nim osoby), a przestępstwo to zostało stwierdzone prawomocnym wyrokiem skazującym.

Za delikt administracyjny w postaci niedopełnienia obowiązku dostarczenia kapitanowi deklaracji o towarach niebezpiecznych lub zanieczyszczających odpowiedzialność ponosi załadowca. Wskazany czyn zagro-

94 Art. 37 pkt 1-18 u.z.z.m.s 
żony jest karą pieniężną do wysokości 50000 SDR $^{95}$. Należy jednak podkreślić, że zakres odpowiedzialności w związku z przewożonymi ładunkami jest szer$\mathrm{szy}^{96}$. Delikt ten stanowi natomiast jedyny przejaw odpowiedzialności załadowcy za zanieczyszczenie wód morskich.
Ponadto niewykonanie obowiązków określonych w przepisach rozporządzenia w sprawie zakazu stosowania związków cynoorganicznych również stanowi delikt administracyjny i podlega karze pieniężnej do wysokości 50000 SDR. W tym przypadku jednak odpowiedzialność może ponieść każdy ${ }^{98}$. Biorąc pod

\section{$\mathrm{Na}$ aprobatę zasługuje zunifikowanie zasad} wymiaru administracyjnej kary pieniężnej w postaci wskazania trzech okoliczności, które powinny być brane pod uwagę przez dyrektora urzędu morskiego przy dokonywaniu wymiaru kary.

Kolejnym wymagającym zwrócenia uwagi deliktem administracyjnym jest niewykonanie obowiązków związanych z dostarczaniem paliwa. Podmiotem odpowiedzialnym jest w tym przypadku dostawca paliwa. Wskazany delikt również podlega karze pieniężnej do wysokości 50000 SDR ${ }^{97}$. Przypomnieć należy, że do obowiązków związanych z dostarczaniem paliwa zalicza się: obowiązek dostarczenia na statek paliwa spełniającego aktualnie obowiązujące wymagania, obowiązek zgłoszenia właściwemu dla miejsca dostaw dyrektorowi urzędu morskiego informacji dotyczących działalności w zakresie dostaw paliwa w polskich obszarach morskich, obowiązek informowania o zmianie danych zawartych w zgłoszeniu, obowiązek składania sprawozdania z działalności (zawierającego co najmniej informację o ilości, rodzaju paliwa sprzedanego w poszczególnych portach, z uwzględnieniem zawartości siarki) oraz obowiązek powiadomienia o zakończeniu działalności w zakresie dostaw paliwa.

\footnotetext{
95 Art. 36b u.z.z.m.s.

96 Odpowiedzialność uregulowana przepisami ustawy z dnia 15 listopada 1984 r. Prawo przewozowe (t.j. Dz.U. 2017, poz. 1983).

97 Art. 36c u.z.z.m.s.
}

uwagę konieczność dążenia do jak najskuteczniejszej ochrony wód morskich przed zanieczyszczeniami, brak ograniczeń podmiotowych należy ocenić pozytywnie.

Naliczanie i wymierzanie administracyjnych kar pieniężnych podmiotom innym niż armatorzy statków również nie jest uzależnione od stwierdzenia winy. Także w przypadku regulacji prawnych w tym zakresie żadna z norm nie wskazuje winy jako przesłanki pociągnięcia do odpowiedzialności za delikt administracyjny. Uwagi dotyczące właściwości organów oraz trybu wymierzania i ściągania analizowanych powyżej kar pieniężnych przedstawione podczas analizy administracyjnych kar pieniężnych nakładanych na armatora pozostają aktualne również w niniejszym przypadku.

\section{Cofnięcie decyzji administracyjnej} jako instrument odpowiedzialności administracyjnej za zanieczyszczanie wód morskich przez statki

Instrumentem odpowiedzialności administracyjnej związanej z zanieczyszczeniami wód morskich przez statki jest także cofnięcie pozwolenia na przeprowadzenie testów metod redukcji emisji. Odpowiedzial-

98 Art. 37a u.z.z.m.s. 
ność w tym zakresie ponoszona jest przez armatora, w przypadku gdy nie spełnia on warunków dopuszczalności przeprowadzenia testów określonych $\mathrm{w}$ art. 13da u.z.z.m.s. Wskazane niespełnienie warunków może być związane z naruszaniem wymagań ochronnych wód morskich w zakresie zagospodarowania odpadów powstałych podczas testów. Decyzja o cofnięciu wydawana jest przez dyrektora urzędu morskiego. Kompetencja przyznana temu organowi została połączona z obowiązkiem czynienia z niej użytku ${ }^{99}$. Decyzja taka ma charakter prewencyjny, a jej głównym celem jest niedopuszczenie do powstania negatywnych konsekwencji dla środowiska. Dostrzec należy także sankcyjny charakter wskazanej decyzji. Wynika on z tego, że niespełnienie warunków dopuszczalności przeprowadzania testów redukcji emisji może wywoływać negatywne konsekwencje wynikające z niewłaściwego zagospodarowania odpadów. Zasygnalizować należy również brak występowania bezpośredniego powiązania sankcji cofnięcia pozwolenia z naruszeniem wymagań określonych w tym pozwoleniu.

\section{Wnioski}

Regulacje prawne w zakresie odpowiedzialności administracyjnej zasługują na aprobatę. Wymierzanie administracyjnych kar pieniężnych w drodze postępowania administracyjnego należy ocenić pozytywnie ze względu na brak konieczności brania udziału w postępowaniu sądowym, które często cechuje długotrwałość. Argumentem przemawiającym za wskazaną oceną jest również podleganie decyzji nakładających administracyjne kary pieniężne kontroli sądów administracyjnych. Ponadto toczące się postępowanie jest dwuinstancyjne, co pozwala stronie niezadowolonej z decyzji dyrektora urzędu morskiego nakładającej administracyjną karę pieniężną wnieść środek odwoławczy do ministra właściwego do spraw gospodarki morskiej. Za istotne uznać należy, że decyzje nakładające kary pieniężne mają charakter decyzji związanych, co przesądza o ograniczeniu procesu ocennego.

$\mathrm{Na}$ aprobatę zasługuje również zunifikowanie zasad wymiaru administracyjnej kary pieniężnej w postaci wskazania trzech okoliczności, które powinny być brane pod uwagę przez dyrektora urzędu morskiego

99 Art. 13 dd u.z.z.m.s. przy dokonywaniu wymiaru kary. Pozytywnie ocenić należy również różnicowanie wagi naruszeń poprzez ustawowe ustalanie jedynie maksymalnej wysokości kary pieniężnej. Z tego względu regulacje prawne określające wytyczne ustalania wysokości kary są niezbędnym elementem obowiązującego systemu prawnego. Warto zwrócić uwagę także na art. 38 ust. 3 u.z.z.m.s. określający przesłanki wyłączające nałożenie kary, który to artykuł zapewnia elastyczność analizowanych regulacji prawnych.

Dodatkowo uniezależnienie odpowiedzialności od winy znacznie ułatwia wykazanie przesłanek pociągnięcia do odpowiedzialności i ukaranie sprawcy naruszenia, co jest korzystne z punktu widzenia skutecznej ochrony wód morskich. Uznać należy, że zobiektywizowanie odpowiedzialności nie prowadzi do postawienia armatora, kapitana statku lub innych członków załogi w nadmiernie niekorzystnej sytuacji. Podmioty te mogą bowiem żądać naprawienia szkody od podmiotu za nią odpowiedzialnego w drodze postępowania cywilnego.

Konkludując, ze względu na precyzyjnie określony katalog deliktów administracyjnych oraz obowiązujące zasady i tryb wymierzania kar za wskazane delikty obecny kształt administracyjnych gwarancji wykonania obowiązków w zakresie ochrony wód morskich przed zanieczyszczeniami ze statków należy ocenić pozytywnie.

\section{Bibliografia}

Barczak A., Model gospodarowania odpadami komunalnymi w Polsce i Niemczech. Analiza porównawczo-prawna, Szczecin [Przedsiębiorstwo Produkcyjno-Handlowe ZAPOL Dmochowski, Sobczyk] 2013.

Boć J., Nowacki K., Samborski-Boć E., Ochrona środowiska, Wrocław [Kolonia Limited] 2005

Bomanowski B., Piotrowski T., Zarys prawnej ochrony przyrody Morza Bałtyckiego przed zanieczyszczeniami ze statków w kontekście interesów podmiotów gospodarujących na Morzu Battyckim (w:) M. Górski (red.), Prawo ochrony przyrody a wolność gospodarcza, Łódź-Poznań [Polskie Zrzeszenie Inżynierów i Techników Sanitarnych. Oddział Wielkopolski] 2011.

Cheda J., Zapobieganie zanieczyszczeniu morza przez statki (w:) P. Korzeniowski (red.), Prawa i obowiązki przedsiębiorców w ochronie środowiska. Zarys encyklopedyczny, Warszawa [Difin] 2010. 
Ciechanowicz-McLean J., Ochrona środowiska morskiego, „Prace Naukowe Uniwersytetu Śląskiego” 2000, nr 1871.

Ciechanowicz-McLean J., Prawo ochrony i zarządzania środowiskiem, Warszawa [Difin] 2015.

Fill W., Charakter administracyjnych kar pieniężnych (na tle prawa ochrony środowiska), „Państwo i Prawo” 2009, nr 6, s. 63-75.

Gotkowicz-Lipowska H., Zanieczyszczenia mórz i oceanów. Zanieczyszczenie morza przez statki - obowiązujące regulacje prawne, Szczecin [Wydawnictwo Naukowe US] 2003.

Górski M., Obowiązek dbania o środowisko (w:) M. Safjan, L. Bosek (red.), Konstytucja RP. Komentarz, t. 1, Warszawa [C.H. Beck] 2016.

Górski M., Odpowiedzialność administracyjnoprawna w ochronie środowiska, Warszawa [Wolters Kluwer] 2008.

Górski M., Odpowiedzialność administracyjno-prawna w ochronie środowiska. Zagadnienia podstawowe, Poznań [Futura, Grzegorz Łuczak] 2007.

Górski M. i in., Prawo ochrony środowiska. Komentarz, Warszawa [Wolters Kluwer] 2014.

Jendrośka J. (red.), Leksykon prawa ochrony środowiska, Warszawa [Wolters Kluwer] 2012.

Jerzmański J., Odpowiedzialność administracyjna (w:) W. Radecki (red.), Instytucje prawa ochrony środowiska. Geneza, rozwój, perspektywy, Warszawa [Difin] 2010.

Kudrzycka A., Postępowanie administracyjne w sprawie wymierzenia administracyjnej kary pieniężnej $w$ prawie ochrony środowiska, „Przegląd Prawa Ochrony Środowiska” 2014, nr 2, s. 135-158.

Kwaśnicka K., Odpowiedzialność administracyjna w prawie ochrony środowiska, Warszawa [Wolters Kluwer] 2011.

Lang W., Struktura odpowiedzialności prawnej, „Zeszyty Naukowe Uniwersytetu Mikołaja Kopernika” 1986, z. 8 (31): Prawo, VIII.

Lipiński A., Prawne podstawy ochrony środowiska, Kraków [Zakamycze] 2005.

Lisicka H., Macek I., Radecki W., Leksykon ochrony środowiska. Prawo i polityka, Wrocław [Wydawnictwo Prawo Ochrony Środowiska] 1999.

Łopuski J. (red.), Prawo morskie, t. 1, Bydgoszcz [Branta] 1996.
Mazurkiewicz M., Opłaty i kary pieniężne w systemie ochrony środowiska w Polsce (struktura prawna i funkcje), Wrocław [Wydawnictwo Uniwersytetu Wrocławskiego] 1986.

Młynarczyk J., Prawo morskie, Gdańsk [Wydawnictwo Uniwersytetu Wrocławskiego] 2002.

Nowicki D.K., Peszkowski S., Kilka uwag o szczególnym charakterze administracyjnych kar pieniężnych (w:) M. Błachucki (red.), Administracyjne kary pieniężne w demokratycznym państwie prawa, Warszawa [Biuro Rzecznika Praw Obywatelskich] 2015. Paczuski R., Prawo ochrony środowiska, Bydgoszcz [Branta] 2000. Popik-Chorąży K., Administracyjna kara pieniężna w ustawie-Prawo ochrony środowiska (w:) J. Stelmasiak (red.), Prawo ochrony środowiska, Warszawa [LexisNexis] 2009.

Popik-Chorąży K., Kara pieniężna w prawie ochrony środowiska, Lublin [Innovatio Press] 2009.

Pyć D., Zużewicz-Wiewórska I. (red.), Leksykon prawa morskiego. 100 podstawowych pojęć, Warszawa [C.H. Beck] 2013.

Radecki W., Kary pieniężne w ochronie środowiska, Bydgoszcz [Branta] 1996.

Radecki W., Kary pieniężne w polskim systemie prawnym czy nowy rodzaj odpowiedzialności karnej, „Przegląd Prawa Karnego” 1996, nr 14-15, s. 5-17.

Radecki W., Odpowiedzialność administracyjna w ochronie środowiska, Wrocław [Zakład Narodowy im. Ossolińskich] 1985.

Radecki W., Odpowiedzialność prawna w ochronie środowiska, Warszawa [Difin] 2002.

Radecki W., Opłaty i kary pieniężne w ochronie środowiska, Warszawa [Difin] 2009.

Rakoczy B., Ciężar dowodu w polskim prawie ochrony środowiska, Warszawa [Wolters Kluwer] 2010.

Rakoczy B., Ewolucja koncepcji odpowiedzialności w polskim prawie ochrony środowiska (w:) M Rudnicki, A. Haładyj, K. Sobieraj (red.), Europeizacja prawa ochrony środowiska, Lublin [Wydawnictwo KUL] 2011.

Sadowski P., Odpowiedzialność administracyjna w ochronie środowiska (w:) J. Stelmasiak (red.), Prawo ochrony środowiska, Warszawa [LexisNexis] 2009.

Skoczylas J., Pojęcie i rodzaje odpowiedzialności prawnej w ochronie środowiska, „Zeszyty Naukowe Szkoły Głównej Służby Pożarniczej” 2011, nr 41, s. 119-132. 